\title{
Purification of water and fertile soil with bentonite-like clays of the Belgorod Region
}

\author{
Alexandr Vezentsev ${ }^{1 *}$, Natalia Volovicheva ${ }^{1}$, Svetlana Korolkova ${ }^{1}$, Lidiia Peristaya ${ }^{1}$, Vitaliy Milyutin ${ }^{2}$, Igor $_{\text {Korolkov }}{ }^{1}$ \\ ${ }^{1}$ Belgorod National State Research University, 308015 Belgorod, Russia \\ ${ }^{2}$ Frumkin Institute of Physical chemistry and Electrochemistry Russian academy of sciences Sciences, 119071 Moscow, Russia
}

\begin{abstract}
This paper presents the results of a comparative assessment of the effectiveness of sorption purification of aquatic medium and fertile soils using native forms of bentonite clays of deposits in the Belgorod region (Russia) from heavy metal ions $\left(\mathrm{Cu}^{2+}, \mathrm{Fe}^{3+}, \mathrm{Cr}^{3+}, \mathrm{Pb}^{2+}\right)$ and radionuclides $\left({ }^{137} \mathrm{Cs},{ }^{85} \mathrm{Sr},{ }^{233} \mathrm{U}\right.$ и $\left.{ }^{239} \mathrm{Pu}\right)$. It was revealed that during the sorption of heavy metal ions $\left(\mathrm{Cu}^{2+}, \mathrm{Fe}^{3+}\right.$ и $\left.\mathrm{Cr}^{3+}\right)$ from model water systems, the most absorbing activity is shown by the natural clays of the Polyana and Nelidovka deposits, which have almost the same ability to absorb heavy metal ions. The purification efficiency of the model aqueous solutions from these cations taken at an initial concentration of $0.1 \mathrm{mmol} / \mathrm{l}$ reaches $95 \%$. It was established that the natural clay of the Polyana deposit is also an effective sorbent for the purification of solutions from cesium radionuclides. In terms of sorption ability, the studied sample is 5 times superior to natural clinoptilolite, which is most often used to purify solutions from radiocesium.. It was revealed that with an increase in the amount of added sorbents, the detoxification effect is increased, that is, the content of heavy metals in the green mass decreases.
\end{abstract}

\section{Introduction}

Pollution of the environment by heavy metals and pathogens is always potentially dangerous due to their introduction from the hydro- and lithosphere through metabolic and trophic chains into living organisms, including humans [1]. In view of the imperfections of treatment systems and structures, various pollutants enter water bodies, deteriorating their sanitary condition and causing the need for special deep purification of water before using it for household and drinking purposes and some industrial purposes. In addition to water purification, another vital problem is the cleaning of soil from heavy metals such as lead, copper, etc. Heavy metals in the soil are of both natural and anthropogenic origin. For example, one of the anthropogenic sources of copper is poisonous chemicals used for a long time in vineyards. Further, through the food chain, soil - plants - animals human heavy metals enter the human body, causing a number of negative effects [2]. Thus, a wide range of harmful and toxic substances entering the environment, and, as a result, into the human body and animals with aerosols, water and food, determines the need to search for and create materials with pronounced sorption selectivity to heavy metals, radionuclides, pathogenic microorganisms and other pollutants. As world practice shows, the most promising and economical method of cleaning the components of the biosphere is the sorption method. The efficiency of purification by this method reaches $80-95 \%$ [3-5].
Currently, bentonites [6-7] are successfully used as adsorption active materials in solving environmental problems. Bentonite-like clays are widespread in the Belgorod region (Russia) in Paleogene deposits. Bentonites are confined to the deposits of the Kiev retinue, folded (from top to bottom) with clays, marls and clay aleurites, which lie at a small (0-15 m) depth. Sediment capacity reaches 25-30 m [8].

The purpose of this work was to study the efficiency of purification of aquatic medium and fertile soils from ions of heavy metals and radionuclides when using bentonite-like clays selected from various deposits and sites of the Belgorod region (Russia) as sorbents.

\section{Research materials and methods}

On the territory of the Belgorod region there are clay materials, a feature of which is the predominance of the montmorillonite-hydromicaceous component, as well as the calcite mineral. In the present work sorption properties of natural forms of clays of fields of the Belgorod region are investigated: Polyana (Shebekinsky district), Nelidovka (Korochansky district), Orlovka and the Top Olshanets (Belgorod district), Sergiyevka (Gubkinsky district) in relation to ions of heavy metals $\left(\mathrm{Cu}^{2+}, \mathrm{Fe}^{3+}\right.$, $\left.\mathrm{Cr}^{3+}, \mathrm{Pb}^{2+}\right)$ and radionuclides $\left({ }^{137} \mathrm{Cs},{ }^{85} \mathrm{Sr},{ }^{233} \mathrm{U}\right.$ and $\left.{ }^{239} \mathrm{Pu}\right)$. Earlier, the authors of this work established the peculiarities of the material composition and textural

*Corresponding author: vesentsev@ bsu.edu.ru 
characteristics of the examined samples of these deposits [9-11].

According to the results of the analysis of the mineralogical composition, the clays of all tested deposits and locations are polymineral systems. The main rockforming minerals in them are montmorillonite, illite, kaolinite, clinoptilolite, feldspar (orthoclase and anorite), as well as low-temperature trigonal quartz and calcite.

As an example, Figure 1 shows an electronic micrograph of a montmorillonite particle from the clay of the Polyana deposit (Shebekinsky district), obtained by us using a JEM - 2100 transmission electron microscope (JEOL, Japan). The figure also shows the microdifraction pattern and the energy dispersion spectrum of this particle.
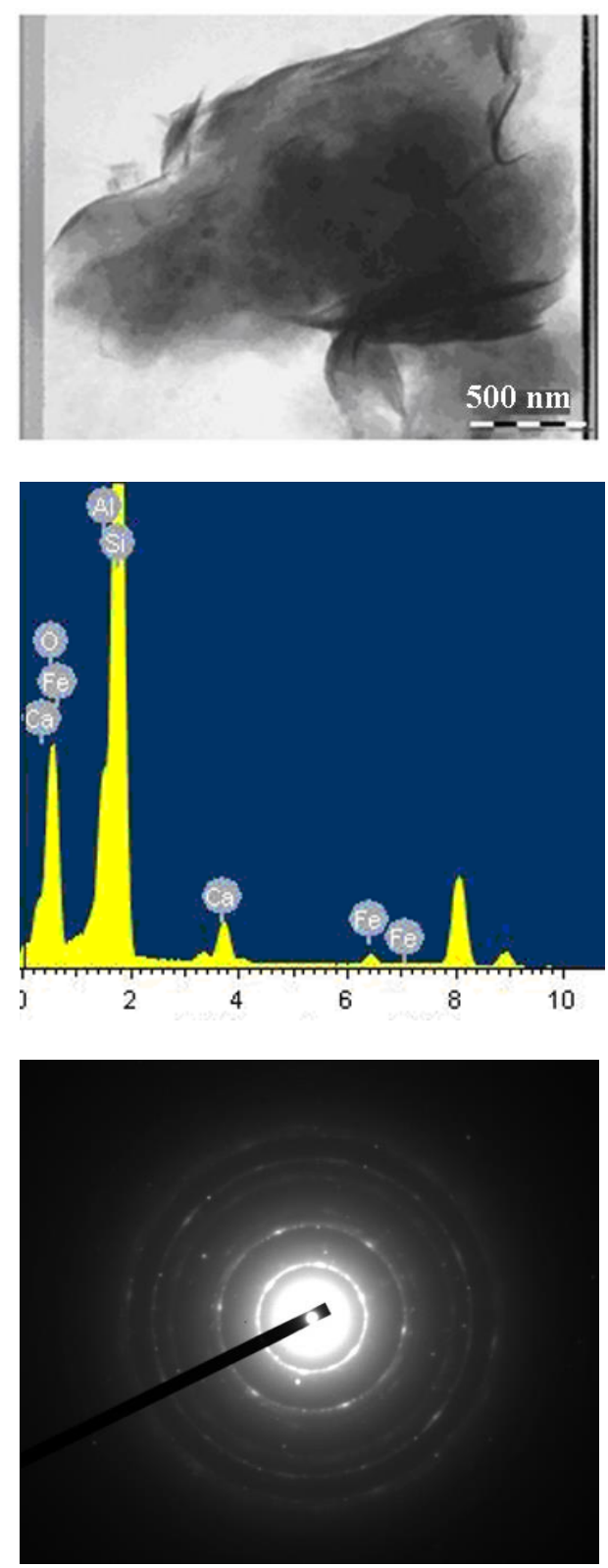

Fig.1. Montmorillonite from the clay of the Polyana deposit (Shebekinsky district): a) microphotography; b) microdifraction pattern; c) energy dispersion spectrum

The particles of this mineral in the preparations have a vague cloud-like appearance, which is typical of montmorillonite. Their size is from fractions to $3-5$ microns.

All montmorillonite particles have a polycrystalline structure, which is manifested both in their morphology and in the microdifraction patterns they form, which, as a rule, have a circular nature of the distribution of reflexes hK0 (Figure $1 \mathrm{~b}$ ). Many particles have numerous bends and bends characteristic of this mineral at the edges, favorable for obtaining microdifraction paintings with reflexes $00 l[12,13]$

On the energy dispersion spectrum of montmorillonite particles from the clay of the Polyana deposit (Fig. 1c) there are peaks: $\mathrm{Si}, \mathrm{O}, \mathrm{Al}, \mathrm{Ca}$ and $\mathrm{Fe}$, the content of these elements is 51.8 , respectively; $33.9 ; 9.52 ; 4.3$ and 0.4 $\mathrm{wt} \%$, which indicates a calcium variety of this mineral.

By the method of adsorption luminescent analysis based on cation-exchange adsorption of organic dyesphosphors by clay with formation of coagulate of organclay complex, we determined mass fraction of sorption active mineral montmorillonite in examined samples (table 1).

Table 1. Content of sorption active montmorillonite in natural clays, $w \mathrm{t} \%$

\begin{tabular}{|c|c|}
\hline $\begin{array}{c}\text { The deposit from which } \\
\text { the clay sample was taken }\end{array}$ & $\begin{array}{c}\text { Montmorillonite } \\
\text { content, wt } \%\end{array}$ \\
\hline Yablonevo & $40.0-45.0$ \\
\hline Sergievka & $47.0-52.0$ \\
\hline Nelidovka & $45.0-49.0$ \\
\hline Top Olshanets & $40.0-45.0$ \\
\hline Orlovka & $35.0-40.0$ \\
\hline Polyana & $58.0-65.0$ \\
\hline
\end{tabular}

The absorption capacity of natural clays with respect to iron (III), chromium (III) and copper (II) ions was determined using model water systems by constructing sorption curves using a variable concentration method. For this purpose, a series of model solutions of salts containing cations $\mathrm{Fe}^{3+}, \mathrm{Cu}^{2+}$ and $\mathrm{Cr}^{3+}$ were prepared. In order to prevent hydrolysis, model aqueous systems with a specified metal ion concentration of $0.1 \mathrm{mmol} / 1$ were acidified with a sulfuric acid solution until the $\mathrm{pH}$ value was maintained at $3.0-3.3$. The experiment was carried out under static conditions at a temperature of $25^{\circ} \mathrm{C}$. The duration of the isothermal step was 60 minutes. The solid/liquid phase ratio was $1: 100$. At the end of the process, the suspensions were filtered. The residual concentration of cations in the solution was determined photometrically at the appropriate wavelength using a Spekord-50 device.

Radionuclide sorption experiments were carried out under static conditions by mixing a slurry of ground sorbent with an aliquot of aqueous solution for 48 hours. The liquid and solid phases were then separated by filtration through a "Blue ribbon" paper filter. In the resulting filtrate, the specific activity of the radionuclide was determined and the distribution coefficient $\left(\mathrm{K}_{\mathrm{d}}\right)$ of the corresponding radionuclide was calculated by the formula (1):

$$
K_{d}=\left(\left(a_{o}-a_{p}\right) / a_{p}\right) \times V_{p} / m_{c}
$$


where is $a_{o}, a_{p}$ - initial and equilibrium specific activity of radionuclide in solution, $\mathrm{Bq} / \mathrm{dm}^{3}$

$\mathrm{V}_{\mathrm{p}}$ - liquid phase volume, $\mathrm{sm}^{3}$;

$\mathrm{m}_{\mathrm{c}}-$ mass of a sorbent, $\mathrm{g}$.

In studying the sorption of radionuclides, tap water of Belgorod composition was used as a liquid phase: total stiffness - $4.19 \mathrm{mg}-\mathrm{eq} / \mathrm{dm} 3$, calcium - $67.8 \mathrm{mg} / \mathrm{dm} 3$, magnesium $-9.5 \mathrm{mg} / \mathrm{dm} 3$, total salt content $-720 \mathrm{mg} / \mathrm{dm}^{3}$, $\mathrm{pH}=7.1$. Before starting the experiments, indicator amounts of radionuclides ${ }^{137} \mathrm{Cs},{ }^{85} \mathrm{Sr},{ }^{233} \mathrm{U},{ }^{239} \mathrm{Pu}$ in an amount of $105-106 \mathrm{~Bq} / \mathrm{dm}^{3}$ were added to the solutions.

Determination of lead and copper in soils and clays was carried out by atomic absorption spectrometry according to the standard method [14]: gross content chemical decomposition of samples with nitric acid (1:1); mobile acid-soluble forms - extraction with $1 \mathrm{n}$ nitric acid; mobile forms available to plants - extraction with acetateammonium buffer solution with $\mathrm{pH}=4.8$.

\section{Discussion of results}

It was established that when using natural clays of investigated deposits of the Belgorod region as sorbents of heavy metal ions from model aqueous solutions, the highest sorption rate is observed in the first 5 minutes of exposure.

Table 2 shows the efficiency of extraction of ions $\mathrm{Cu}^{2}$, $\mathrm{Fe}^{3}$ and $\mathrm{Cr}^{3}$ from aqueous solutions by experimental sorbents (sorption duration was 60 minutes).

Table 2. Efficiency of sorption of heavy metal ions by natural clays

\begin{tabular}{|c|c|c|c|}
\hline \multirow{2}{*}{ Layer } & \multicolumn{3}{|c|}{ Sorption efficiency beyond } \\
& $\mathrm{Cu}^{2+}$ & $\mathrm{Fe}^{3+}$ & $\mathrm{Cr}^{3+}$ \\
\hline Polyana & 95 & 95 & 95 \\
\hline Nelidovka & 94 & 95 & 94 \\
\hline Top Olshanets & 72 & 90 & 90 \\
\hline Orlovka & 70 & 63 & 67 \\
\hline
\end{tabular}

Comparative analysis of Table 2 showed that the efficiency of cleaning model aqueous solutions from heavy metal ions with a concentration of $0.1 \mathrm{mmol} / 1$ by natural clays of the Polyana and Nelidovka deposits reaches $95 \%$. As for Oryol clay, when used as a sorbent, the purification efficiency of model aqueous solutions is relatively low. It is inferior to Polyanskaya and Nelidovskaya clays on the $20-30 \%$. The residual concentration of iron (III) ions in the model solution during sorption purification by Oryol clay is $0.034 \mathrm{mmol} / \mathrm{l}$ $(1.90 \mathrm{mg} / \mathrm{l})$, chromium (III) ions - $0.033 \mathrm{mmol} / \mathrm{l}(1.72$ $\mathrm{mg} / \mathrm{l}$ ), and copper (II) ions - $0.029 \mathrm{mmol} / 1$ (1.86 mg/l).

It was established that during the sorption of heavy metal ions $\left(\mathrm{Cu}^{2}, \mathrm{Fe}^{3}\right.$ and $\left.\mathrm{Cr}^{3}\right)$, the most sorption activity is shown by the natural clays of the Polyana and Nelidovka deposits, which have almost the same ability to absorb heavy metal ions. Top Olshanets clay is inferior in its sorption ability to Polyansky and Nelidovsky samples 1.52 times. Reduction of concentration of metal ions in model aqueous solutions occurs as a result of sorption, epitaxial-destructive, ion-exchange processes, as well as due to formation of hardly soluble hydroxides.

Experimental work to study the sorption characteristics of the natural clay of the Polyana deposit in relation to the radionuclides ${ }^{137} \mathrm{Cs},{ }^{85} \mathrm{Sr},{ }^{233} \mathrm{U}$ and ${ }^{239} \mathrm{Pu}$ was carried out in the laboratory of chromatography of radioactive elements of the Institute of Physical Chemistry and Electrochemistry named after A.N. Frumkin RAS.

Specific activity of radionuclides in solutions was determined by direct radiometric method using the spectrometric complex CKC-50M (Green Star Technologies, Russia).

Table 3 shows the values of the distribution coefficients $(\mathrm{Kd}){ }^{137} \mathrm{Cs},{ }^{85} \mathrm{Sr},{ }^{233} \mathrm{U}$ and ${ }^{239} \mathrm{Pu}$ on the test samples. For comparison, in similar conditions, the $\mathrm{Kd}$ values of the above radionuclides were determined on the clinoptilolite of the Shivertuyskoye deposit (Chita region), which is currently used as a radionuclide sorbent.

Table 3. Values Of distribution coefficient $\left(\mathrm{k}_{\mathrm{d}}\right)$ of radionuclides ${ }^{137} \mathrm{cs},{ }^{85} \mathrm{sr},{ }^{233} \mathrm{u}$ And ${ }^{239} \mathrm{pu}$ during sorption from tap water on natural clay of polyana deposit and on clinoptilolite

\begin{tabular}{|c|c|c|c|c|}
\hline \multirow{2}{*}{ Sorbetn type } & \multicolumn{4}{|c|}{$\mathrm{K}_{\mathrm{d}}{ }^{137} \mathrm{Cs}, \mathrm{sm}^{3} / \mathrm{g}$ of radionucleides } \\
\cline { 2 - 5 } & ${ }^{137} \mathrm{Cs}$ & ${ }^{85} \mathrm{Sr}$ & ${ }^{233} \mathrm{U}$ & ${ }^{239} \mathrm{Pu}$ \\
\hline $\begin{array}{c}\text { Clay of } \\
\text { Polyana } \\
\text { layer }\end{array}$ & $\begin{array}{c}(6.0 \pm 0.4) \\
\times 10^{4}\end{array}$ & $330 \pm 20$ & $29 \pm 3$ & $85 \pm 8$ \\
\hline Clinoptilotite & $\begin{array}{c}(1.1 \pm 0.2) \\
\times 10^{4}\end{array}$ & $580 \pm 40$ & $90 \pm 7$ & $97 \pm 6$ \\
\hline
\end{tabular}

It has been found that natural clay is an effective sorbent for cleaning solutions from cesium radionuclides. In terms of sorption ability, the studied sample is 6 times superior to natural clinoptilolite, which is most often used to purify solutions from radiocesium.

The sorption of strontium, uranium and plutonium radionuclides on the studied clay sample proceeds much worse. The values of $\mathrm{Kd}$ during sorption of these radionuclides from tap water are 3 orders of magnitude lower than the corresponding values during sorption of cesium.

Low sorption values of $\mathrm{Sr}$ are related to competition of $\mathrm{Ca}$ ions present in tap water [15]. The best sorption characteristics with respect to ${ }^{85} \mathrm{Sr}$ are natural clinoptilolite.

Low sorption of $U$ is due to the fact that $U$ in tap water is in the form of strong anionic tricarbonate complexes [16], which are poorly absorbed on cation-exchange groups of clays.

Low sorption characteristics of the analysed samples with respect to $239 \mathrm{Pu}$ are explained by the fact that $\mathrm{Pu}$ in tap water is in fully hydrolyzed form [17]. Partial absorption of $\mathrm{Pu}$ is associated with adsorption of its colloidal forms on the surface of the sorption material.

Based on the experimental work carried out on the use of investigated natural clays of the Belgorod region in the process of purification of aqueous media from ions of heavy metals and radionuclides, it was found that the most promising material is a sample taken from the Polyana deposit. Therefore, this sorption active material was chosen by us to continue research aimed at studying the 
efficiency of cleaning the fertile soil layer from ions of heavy metals (copper and lead). Also, for this purpose, we tested a sample of bentonite-like clay taken from the Sergievka deposit of the Gubkinsky district of the Belgorod region.

The experimental work was carried out in two stages. At the first stage, laboratory studies were carried out using buffer soil extracts. The initial concentration of mobile forms of copper and lead available to plants in the buffer extract from a soil sample, established by atomic absorption spectrometry, was: $\mathrm{Cu}^{2+} 2.0 \mathrm{mg} / \mathrm{kg}, \mathrm{Pb}^{2+} 1.20$ $\mathrm{mg} / \mathrm{kg}$.

Sorption was carried out at constant temperature $\left(20^{\circ} \mathrm{C}\right)$ under static conditions for 90 minutes. Sorbent (clay) was taken in an amount of $0.1 ; 0.5 ; 1.0 ; 3.0$ and 5.0 $\mathrm{g}$ per $50 \mathrm{ml}$ buffer extract. The results of the soil clay treatment are shown in Table 4.

The results shown in Table 4 show that with an increase in sorbent weight from $0.1 \mathrm{~g}$ to $5.0 \mathrm{~g}$, the degree of purification of the buffer extract by clay taken from the middle layer from ions $\mathrm{Cu}^{2}$ increases from 45.5 to $95.5 \%$, and from ions $\mathrm{Pb}^{2+}$ - from 33.3 to $83.3 \%$.

The degree of purification of the buffer extract with clay taken from the lower layer with the same increase in sorbent weight increased from 54.5 to $95.5 \%$ (for $\mathrm{Cu}^{2}$ ) and from 33.3 to $83.3 \%$ (for $\mathrm{Pb}^{2+}$ ).

Table 4. Degree of cleaning of soil buffer clay of Sergievka deposit

\begin{tabular}{|c|c|c|c|c|}
\hline \multirow{2}{*}{ Sorbent mass, g } & \multicolumn{2}{|c|}{ Center, wt \% } & \multicolumn{2}{c|}{$\begin{array}{c}\text { Lower } \\
\text { layer, wt \% }\end{array}$} \\
\cline { 2 - 5 } & $\mathrm{Cu}^{2+}$ & $\mathrm{Pb}^{2+}$ & $\mathrm{Cu}^{2+}$ & $\mathrm{Pb}^{2+}$ \\
\hline 0.1 & 45.5 & 33.3 & 54.5 & 33.3 \\
\hline 0.5 & 70.5 & 45.8 & 68.2 & 58.3 \\
\hline 1.0 & 72.3 & 58.3 & 79.5 & 58.3 \\
\hline 3.0 & 86.4 & 75.0 & 87.3 & 83.3 \\
\hline 5.0 & 95.5 & 83.3 & 95.5 & 83.3 \\
\hline
\end{tabular}

Therefore, purification of the buffer extract from copper ions by these clays is more effective than from lead ions. Studies have shown that the optimal ratio of clay to soil is 1:5. At this ratio, the degree of soil purification with clay is: for copper ions $95.5 \mathrm{wt} \%$, for lead ions $83.3 \mathrm{wt} \%$.

The second stage of experimental work consisted in conducting experimental testing studies in the field and was aimed at studying the growth intensity and yield of radish and corn plants of the F1-Sandrina variety, depending on the dose of clay sorbents previously introduced into the soil.

Studies with radishes were carried out by the vegetation method. Universal peat grunt is used as soil nutrient medium. Before the start of sowing, the soil peat was pre-infected with copper ions, which were introduced into the soil as an aqueous solution of copper sulfate pentahydrate $-\mathrm{CuSO}_{4} \cdot 5 \mathrm{H}_{2} \mathrm{O}$ at a rate of $198 \mathrm{mg}$ of $\mathrm{Cu}^{2+}$ ions per square meter. As a sorbent, clay of the Polyana deposit of the Belgorod region was added to the soil at a rate of $90 \mathrm{~g} / \mathrm{m} 2$. The experiment was carried out according to a scheme comprising three test variants: 1 . "clean" soil (control); 2. soil copper salt; 3 . soil salt copper clay.
Table 5 shows the total (gross) copper content of soil samples and the content of mobile copper compounds as well as the $\mathrm{pH}$ of the three soil samples.

The studies carried out yielded the following results. The total (gross) copper content in the initial sample No. 1 studied, in the so-called "pure" soil is $69.0 \mathrm{mg} / \mathrm{kg}$ or 6.9 10-3 mass \%. According to V.V. Kovalsky, the normal copper content in soils is (1.5-6.0) 10-3 wt\% [18]. Therefore, the gross copper content of the original peat soil sample (No. 1) is insignificantly higher than normal. Content of mobile copper compounds extracted by acetate-ammonium buffer solution in initial sample corresponds to maximum permissible concentration of 3 $\mathrm{mg} / \mathrm{kg}$ [19].

Table 5. Copper content in three soil sample

\begin{tabular}{|c|c|c|c|c|c|}
\hline \multicolumn{2}{|c|}{$\begin{array}{l}\text { Experiment } \\
\text { variant }\end{array}$} & \multirow{3}{*}{$\begin{array}{l}\text { Gross } \\
\text { copper } \\
\text { content, } \\
\mathrm{mg} / \mathrm{kg}\end{array}$} & $\begin{array}{l}\text { Mobile } \\
\text { compound }\end{array}$ & $\begin{array}{l}\mathrm{per} \\
\mathrm{ng} / \mathrm{kg}\end{array}$ & $\begin{array}{l}\mathrm{pH} \\
\text { of }\end{array}$ \\
\hline \multirow[b]{2}{*}{ № } & \multirow[b]{2}{*}{ Soil type } & & The extractin & solution & \\
\hline & & & $\begin{array}{c}\text { acetate- } \\
\text { ammonium } \\
\text { buffer } \\
\text { solution } \\
\text { with pH } 4.8\end{array}$ & $\begin{array}{r}1 \mathrm{H} . \\
\mathrm{HNO}_{3}\end{array}$ & \\
\hline 1 & $\begin{array}{c}\text { «pure» } \\
\text { soil }\end{array}$ & 69 & 3.0 & 5.1 & 6.27 \\
\hline 2 & soil $+\mathrm{Cu}^{2+}$ & 170 & 3.9 & 22.6 & 5.91 \\
\hline 3 & $\begin{array}{c}\text { soil }+\mathrm{Cu}^{2+} \\
+ \text { clay }\end{array}$ & 110 & 2.6 & 19.0 & 6.26 \\
\hline
\end{tabular}

When copper sulfate was added to the soil in the above amount, the gross copper content increased from 69.0 to $170.0 \mathrm{mg} / \mathrm{kg}$ (sample No. 2). After the clay was added to the soil artificially contaminated with copper, the gross copper content decreased to $110.0 \mathrm{mg} / \mathrm{kg}$ (sample No. 3), and the content of mobile copper compounds decreased significantly: from 3.9 to $2.6 \mathrm{mg} / \mathrm{kg}$. Thus, the investigated clay of the Polyana deposit, taken in the indicated amount $\left(90 \mathrm{~g} / \mathrm{m}^{2}\right)$, allows reducing the content of mobile forms of copper in contaminated soils to a concentration below the maximum permissible. Similar changes in copper content are observed when it is extracted from the soil $1 \mathrm{~N}$. nitric acid. It follows from Table 4 that clay reduces the concentration of hydrogen ions and accordingly increases soil $\mathrm{pH}$ by cation exchange. Therefore, the application of clay is a positive factor in the fight against acidification of fertile soil.

We have shown that excessive copper content in soil adversely affects the growth and development of radishes (Table 6).

When visually evaluating the appearance of the radish, it was found that the plants dry, the leaves are coiled, have a pale color, chlorosis is observed. The formation of root crops did not happen. Especially clearly, these features are noted with soil sample No 2, where the copper content is greater than in other samples. They have a smaller stem height and leaf area, as illustrated in Table 6. This is due to the higher content of mobile, water-soluble forms of copper available to plants. 
Table 6. Effect Of $\mathrm{Cu}^{2+}$ And Sorption Active Clay Ions On Stem Height And Radish Leaf Area

\begin{tabular}{|c|c|c|c|c|}
\hline \multicolumn{2}{|c|}{$\begin{array}{c}\text { Experiment } \\
\text { variant }\end{array}$} & $\begin{array}{c}\text { Content of } \\
\text { mobile } \\
\text { forms of } \\
\text { copper in } \\
\text { soil, } \mathrm{mg} / \mathrm{g}\end{array}$ & $\begin{array}{c}\text { Height of } \\
\text { a stalk, } \\
\mathrm{cm}\end{array}$ & $\begin{array}{c}\text { Area of a } \\
\text { leaf, } \mathrm{cm}^{2}\end{array}$ \\
\hline 1 & «pure» soil & 3.0 & 5.6 & 11.09 \\
\hline 2 & soil $+\mathrm{Cu}^{2+}$ & 3.9 & 4.8 & 9.00 \\
\hline 3 & $\begin{array}{c}\text { soil }+\mathrm{Cu}^{2+} \\
+ \text { clay }\end{array}$ & 2.6 & 5.5 & 10.80 \\
\hline
\end{tabular}

At the same time, field experience was laid to study the effect on corn of the variety "F1 - Sandrina" of natural nanostructured sorption active materials based on clay rocks of the Belgorod region according to the scheme presented in Table 7.

Table 7. Field Experience Laying Diagram For Assessment Of Clay Sorbents Efficiency

\begin{tabular}{|c|c|}
\hline $\begin{array}{l}\text { Experiment } \\
\text { variant }\end{array}$ & Characteristic of basic data \\
\hline 1 & Control (corn planted) \\
\hline 2 & $\begin{array}{l}\text { Corn sorbent (Polyana clay in the } \\
\text { amount of } 51 \mathrm{~g} / \mathrm{m}^{2} \text { ) }\end{array}$ \\
\hline 3 & $\begin{array}{l}\text { Corn sorbent (clay of Polyana deposit } \\
\text { in the amount of } 90 \mathrm{~g} / \mathrm{m}^{2} \text { ) }\end{array}$ \\
\hline 4 & $\begin{array}{l}\text { Corn sorbent (clay of Polyana deposit } \\
\text { in the amount of } 129 \mathrm{~g} / \mathrm{m}^{2} \text { ) }\end{array}$ \\
\hline 5 & $\begin{array}{l}\text { Corn sorbent (clay of the Sergievka } \\
\text { deposit (middle layer) in an amount of } \\
\left.51 \mathrm{~g} / \mathrm{m}^{2}\right)\end{array}$ \\
\hline 6 & $\begin{array}{c}\text { Corn sorbent (clay of the Sergievka } \\
\text { deposit (middle layer) in the amount of } \\
\left.90 \mathrm{~g} / \mathrm{m}^{2}\right)\end{array}$ \\
\hline 7 & $\begin{array}{l}\text { Corn sorbent (clay of the Sergievka } \\
\text { deposit (middle layer) in the amount of } \\
129 \mathrm{~g} / \mathrm{m}^{2} \text { ) }\end{array}$ \\
\hline 8 & $\begin{array}{l}\text { Corn sorbent (clay of Polyana deposit } \\
\left.\text { in the amount of } 90 \mathrm{~g} / \mathrm{m}^{2}\right) .+ \text { solutions of } \\
\text { salts } \mathrm{CuSO}_{4} \cdot 5 \mathrm{H}_{2} \mathrm{O} \text { with concentration } \\
\text { of } \mathrm{Cu}^{+2} \text { ions } 198 \mathrm{mg} / \mathrm{m}^{2} \text { and } \mathrm{Pb} \\
\left(\mathrm{CH}_{3} \mathrm{COO}\right)_{2} \cdot 3 \mathrm{H}_{2} \mathrm{O} \text { with concentration } \\
\text { of } \mathrm{Pb}^{+2} \text { ions } 185 \mathrm{mg} / \mathrm{m}^{2}\end{array}$ \\
\hline 9 & $\begin{array}{c}\text { Corn }+ \text { sorbent (clay of the Sergievka } \\
\text { deposit (middle layer) in the amount of } \\
\left.90 \mathrm{~g} / \mathrm{m}^{2}\right) .+ \text { solutions of salts } \mathrm{CuSO}_{4} \\
\cdot 5 \mathrm{H}_{2} \mathrm{O} \text { with concentration of ions } \\
\mathrm{Cu}^{+2} 198 \mathrm{mg} / \mathrm{m}^{2} \text { and } \mathrm{Pb} \\
\left(\mathrm{CH}_{3} \mathrm{COO}\right)_{2} \cdot 3 \mathrm{H}_{2} \mathrm{O} \text { with concentration } \\
\text { of ions } \mathrm{Pb}^{+2} 185 \mathrm{mg} / 1 \mathrm{~m}^{2} \text {. }\end{array}$ \\
\hline 10 & $\begin{array}{c}\text { Corn }+ \text { sorbent activated carbon } \\
\text { Agrosorb }-120 \mathrm{~g} / \mathrm{m}^{2} \text { solutions of salts } \\
\mathrm{CuSO}_{4} \cdot 5 \mathrm{H}_{2} \mathrm{O} \text { with concentration of ions } \\
\mathrm{Cu}^{+2} 198 \mathrm{mg} / \mathrm{m}^{2} \text { and } \mathrm{Pb} \\
\left(\mathrm{CH}_{3} \mathrm{COO}\right)_{2} \cdot 3 \mathrm{H}_{2} \mathrm{O} \text { with concentration } \\
\text { of ions } \mathrm{Pb}^{+2}, 185 \mathrm{mg} / \mathrm{m}^{2} \text {. }\end{array}$ \\
\hline
\end{tabular}

In the process of experimental testing, the growth intensity of the above-ground part of plants was observed, depending on the dose of the sorbent previously introduced into the soil.

A control measurement of the height of the aboveground part of corn plants of the F1 - Sandrina variety, produced 2 months after planting (phase of the fifth to sixth sheets), made it possible to construct the growth diagram shown in Figure 2.

Analysis of the data of the diagram shows that the preliminary introduction of sorbents developed on the basis of clays of the Belgorod region (Polyana field sections 2-4 and 8; Sergievka deposit - areas 5-7 and 9) has a visible positive effect on the process of corn growth. The above-ground parts of plants grown in these areas are on average 2-2.5 times higher than those grown in the protective zone and in the control area. Additional contamination of the soil with cations $\mathrm{Cu}^{2+}$ and $\mathrm{Pb}^{2+}$ produced at sites 8,9 and 10 did not cause inhibition of corn, therefore, it can be concluded that the sorbent added to these sites "bound" the cations $\mathrm{Cu}^{2+}$ and $\mathrm{Pb}^{2+}$ into forms inaccessible to corn.

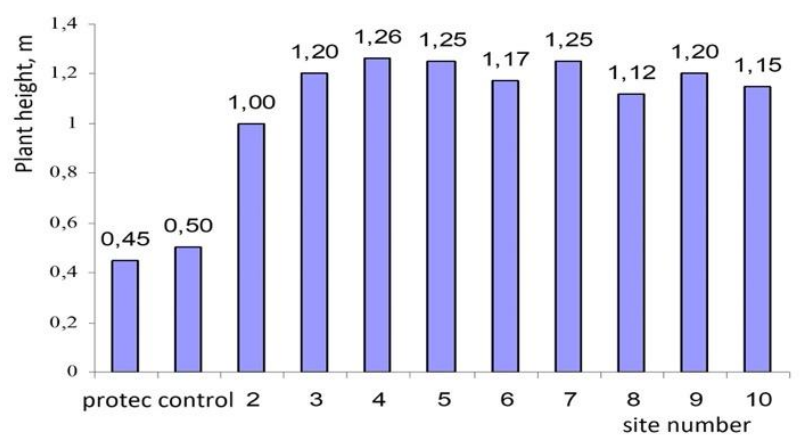

Fig. 2. Diagram of the average height of corn plants (phase of the fifth to sixth sheets), depending on the dose of sorbent previously introduced into the soil, site numbers according to the field experience laying act

It is worth noting that the activated carbon Agrosorb1 (site 10), introduced for the purpose of comparison as a sorbent, also showed a positive effect on plant growth. However, the height of the aboveground part of corn in this area is $5-10 \%$ lower than that of corn in areas where clays of the Belgorod region were used as a sorbent

At the stage of crop maturity, an assessment of the quality of the products obtained as a result of experimental field testing of the addition of detoxicant additive based on the developed sorption active clays of the Belgorod region is given. The weight of the plant mass, as well as the content of heavy metals $\left(\mathrm{Cu}^{2+}\right.$ and $\left.\mathrm{Pb}^{2+}\right)$ in the cobs and stem-leaf part were evaluated

By atomic adsorption spectroscopy, the content of $\mathrm{Cu}^{2+}$ and $\mathrm{Pb}^{2+}$ cations in the green mass was determined, as shown in Table 8.

Analysis of Table 8 shows that both copper cations and lead cations in the maize stem and leaf are lower than the allowable level of these metals in crop production. However, the content of $\mathrm{Cu}^{2+}$ and $\mathrm{Pb}^{2+}$ in the plant samples grown at the control site is slightly greater than in the sites where the clays were previously added. As the amount of added sorbents increases, the detoxification effect is enhanced, i.e. the content of heavy metals in the green mass is reduced

The obtained data showed that it is most effective to bind heavy metal cations to a form of clay of the Polyana deposit inaccessible to plants. In particular, this is noticeable when analyzing the content of $\mathrm{Cu}^{2+}$ and $\mathrm{Pb}^{2+}$ 
cations in plant samples grown at sites previously infected with these metals (sites 8 and 9). The content of copper in the stem-and-leaf part of corn removed from the area where said clay was used as a detoxicant additive (section 8 ) is almost 5 times lower than in the green mass of corn removed from the area where the sorbent based on the clay of the Sergievka deposit (section 9) was previously introduced, and the lead content is 1.2 times less in the same samples. The active coal sorbent Agrosorb-1 also absorbs copper and lead cations but is less effective than clays.

Table 8. Average content of cations $\mathrm{Cu}^{2+} \mathrm{And} \mathrm{Pb}^{2+} \mathrm{In}$ the green corn mass of the upper stem with leaves

\begin{tabular}{|c|c|c|c|c|c|}
\hline $\begin{array}{c}\text { No. of } \\
\text { the area } \\
\text { from } \\
\text { which } \\
\text { the } \\
\text { sample } \\
\text { was } \\
\text { taken }\end{array}$ & \multicolumn{2}{|c|}{$\begin{array}{c}\text { Metal cation } \\
\text { content in dry } \\
\text { matter, } \mathrm{mg} / \mathrm{kg}\end{array}$} & $\begin{array}{c}\text { Content of metal } \\
\text { cations in natural } \\
\text { substance, } \\
\mathrm{mg} / \mathrm{kg}^{4}\end{array}$ & $\begin{array}{c}\text { Mass } \\
\text { fraction of } \\
\text { moisture, } \\
\%\end{array}$ \\
\hline Control & 4.15 & 2.50 & 3.465 & 2.088 & 16.50 \\
\hline 2 & 3.10 & 2.10 & 2.818 & 1.909 & 9.10 \\
\hline 3 & 3.10 & 1.85 & 2.809 & 1.676 & 9.40 \\
\hline 4 & 2.70 & 2.10 & 2.468 & 1.919 & 8.60 \\
\hline 5 & 2.20 & 1.50 & 1.839 & 1.254 & 16.40 \\
\hline 6 & 3.20 & 2.10 & 2.861 & 1.877 & 10.60 \\
\hline 7 & 1.35 & 1.60 & 1.230 & 1.458 & 8.90 \\
\hline 8 & 1.95 & 1.70 & 1.775 & 1.547 & 9.0 \\
\hline 9 & 6.10 & 1.85 & 5.423 & 1.645 & 11.10 \\
\hline 10 & 3.85 & 2.30 & 3.176 & 1.898 & 17.50 \\
\hline
\end{tabular}

The cation content of $\mathrm{Cu}^{2+}$ and $\mathrm{Pb}^{2+}$ in the cobs of corn grown in the test site is shown in the Table 9.

Table9. Average content of cations $\mathrm{Cu}^{2+}$ And $\mathrm{Pb}^{2+}$ in the green corn mass of the upper stem with leaves

\begin{tabular}{|c|c|c|c|c|c|}
\hline \multirow{2}{*}{$\begin{array}{c}\text { No. of the } \\
\text { area from } \\
\text { which the } \\
\text { sample } \\
\text { was taken }\end{array}$} & \multicolumn{2}{|c|}{$\begin{array}{c}\text { Metal cation } \\
\text { content in dry } \\
\text { matter, } \mathrm{mg} / \mathrm{kg}\end{array}$} & \multicolumn{2}{c|}{$\begin{array}{c}\text { Content of metal } \\
\text { cations in natural } \\
\text { substance, } \mathrm{mg} / \mathrm{kg}^{4}\end{array}$} & $\begin{array}{c}\text { Mass } \\
\text { fraction of } \\
\text { moisture, } \\
\%\end{array}$ \\
\hline $\begin{array}{c}\text { Control } \\
\text { (without } \\
\text { sorbent) }\end{array}$ & 7.30 & 0.55 & 5.418 & 0.408 & 25.78 \\
\hline 2 & 6.60 & 0.40 & 4.733 & 0.289 & 27.68 \\
\hline 3 & 5.75 & 0.35 & 3.996 & 0.243 & 30.50 \\
\hline 4 & 6.85 & 0.40 & 5.450 & 0.301 & 24.83 \\
\hline 5 & 6.40 & 0.45 & 4.806 & 0.338 & 24.90 \\
\hline 6 & 6.95 & 0.45 & 5.027 & 0.313 & 30.48 \\
\hline 7 & 6.95 & 0.40 & 4.477 & 0.389 & 18.53 \\
\hline 8 & 4.20 & 0.45 & 3.023 & 0.368 & 28.03 \\
\hline 9 & 2.45 & 0.40 & 2.029 & 0.331 & 17.18 \\
\hline 10 & 4.60 & 0.40 & 3.571 & 0.310 & 22.38 \\
\hline
\end{tabular}

The data presented in Table 9 confirm the conclusions of the analysis of Table 8 . However, it is noteworthy that the $\mathrm{Cu}^{2+}$ content of corn grains is higher than that of green mass. This can be explained by the fact that the mass of copper cations is relatively low and therefore their migration together with other solutes from the soil along the conducting system of the plant is easier, unlike lead cations.

It should be noted that the absorption capacity of the sorbent increases with increasing concentration of heavy metal cations.

Thus, the studies conducted show that the bentonitelike clays of the Polyana deposit are most effective for cleaning the soil from copper and lead ions. The optimal amount of sorbent is $90 \mathrm{~g}$, introduced per $1 \mathrm{~m}^{2}$, or $900 \mathrm{~kg}$ per 1 ha of soil.

\section{Conclusion}

The presented results of experimental studies made it possible to conclude that the most promising universal sorption active material for cleaning such components of the biosphere as water and soil is the natural bentonitelike clay of the Polyana deposit of the Shebekinsky district of the Belgorod region. Said native clay exhibits good absorbency to heavy metal ions and radionuclides, since it is characterized by a higher content of montmorillonite mineral, compared to samples of other clays of the Belgorod region.

It is possible to propose the following mechanism of binding heavy metal cations with sorption active montmorillonite, based on possible substitution of mobile cations in structure of its crystal lattice with ions of heavy metals with close ion radius, for example, $\mathrm{K}^{+}(0.133 \mathrm{~nm})$ at $\mathrm{Pb}^{2+}(0.126 \mathrm{~nm}), \mathrm{Na}^{+}(0.098 \mathrm{~nm})$ at $\mathrm{Cu}^{2+}(0.08 \mathrm{~nm})$ [20, 21]. Absorption of metal ions by montmorillonite occurs both by cationic exchange in inter-packet positions and by adsorption on the outer surface, primarily on the end portion of the laminated crystals, having the output of the active centers, which are uncompensated bonds.

\section{References}

1. A.V. Skalny, M.: Publishing house "ONICS 21 century,", 216, (2004)

2. T.V. Pleteneva, "Toxicological chemistry," (GEOTAR - Media, Moscow, p.512, 2005)

3. I.N. Lozanovskaya, D.S. Orlov, L.K. Sadovnikova, "Ecology and protection of the biosphere during chemical pollution," M.: Higher School, p.168. (1998)

4. L.F. Goldovskaya, Environmental Chemistry - 2nd edition, (World; BINOM. Laboratory of knowledge, Moscow, p.295, 2008)

5. F.T. Bintam, M. Costa, I. "Eichenberger Some issues of metal ion toxicity," M.: World, p.367, (1993)

6. N. Volovicheva, A. Vezentsev, S. Korolkova, P. Sokolovskiy, International Journal of Applied Engineering Research,. 10, 3138-31388, (2015) 
7. T. Vengris, T. Vengris, R. Binkiene, A. Sveikauskaite, Appl. Clay Sci., 18, 183-190, (2001)

8. A.I. Vezentsev, M.A. Trubitsyn, A.A. Romanshchak, Mining magazine, 1, 51-52. (2004)

9. A.I. Vezentsev, S.V. Korolkova, N.A. Volovicheva, Sorption and chromatographic processes, 5, pp. 790-795, (2008)

10. A.I Vezentsev, S.V. Korolkova, V.D. Bukhanov, Scientific statements of Belgorod State University. Series Natural Sciences, 9, pp. 119-123, (2010)

11. A.I. Vezentsev, M.A. Trubitsyn, L.F. GoldovskayaPeristaya, N.A. Volovicheva, Scientific statements of Belgorod State University. Series Natural Sciences, 3, 172-175, (2008)

12. R.E. Grim, Applied clay mineralogy (.McGraw-Hill, New York, p.422, 1962)

13. F. Bergaya, B.K.G.Theng, G. Lagaly, Hand book of clay science, (Elsevier, Netherlands p.1125, (2006)

14. Methodological guidelines for the definition of metals in farmland soils and crop production (TsINAO, Moscow: p. 61, 1992)
15. V.V. Milyutin, V.M. Gelis, GPKh. 67, 1776-1779, (1994)

16. Ed. J. Katz, G. Seaborg, L. Morss, "Chemistry of actinoids: In 3 vols.: Translated from English, (World, Moscow, 1, p. 525, 1991)

17. Ed. J. Katz, G. Seaborg, L. Morss, "Chemistry of actinoids: In 3 vols.: Translated from English, (World, Moscow, 1, p. 647., 1999)

18. V.V. Kovalsky, "Geochemical ecology, ( Science, Moscow, p.150, 1974)

19. MPC of chemicals in soil. Hygienic standards. No. 2.1.7.2041-06.

20. Chemist's Handbook. Volume 1/Under. Reduction of B.P. Nikolsky, p. 382.

21. M. Baghernejad, F. Javaher, A.A. Moosavi, Agronomy and Soil Science, 61, 1061-1077, (2015) 